\title{
ANALISIS PASAL 1242 KITAB UNDANG-UNDANG HUKUM PERDATA UNTUK \\ TIDAK BERBUAT SESUATU SEBAGAI HAK DAN KEWAJIBAN DALAM \\ PERJANJIAN PINJAM MEMINJAM
}

\author{
SUTRISNI \\ Fakultas Hukum Universitas Wiraraja Sumenep \\ sutrisnioke@yahoo.com \\ YAYUK SUGIARTI \\ Dosen Fakultas Hukum Universitas Wiraraja Sumenep \\ Yayuksugiarti66@yahoo.co.id
}

\begin{abstract}
ABSTRAK
Suatu perjanjian dapat timbul karena adanya kesepakatan antara para pihak yang sepakat untuk melaksanakan perjanjian tersebut sebagaimana mestinya. Di dalam suatu perjanjian para pihak memiliki hak dan kewajiban yang harus dihormati dan dilaksanakan dengan baik. Apabila salah satu pihak tidak melaksanakan perjanjian yang telah disepakat, maka pihak tersebut melakukan wanprestasi. Untuk mengetahui pihak tersebut melakukan wanprestasi yaitu apabila tidak memenuhi prestasi sesuai waktu yang telah disepakati.

Untuk memberikan peringatan terhadap pihak yang melakukan wanprestasi agar dapat segera memenuhi prestasi,yaitu dengan dilakukan peringatan tertulis secara resmi dan peringatan tertulis secara tidak resmi. Peringatan tertulis secara resmi dapat dilakukan melalui pengadilan negeri yang berwenang, sedangkan peringatan tertulis tidak resmi dapat dilakukan melalui surat tercatat,telegram,faksimile atau disampaikan secara langsung terhadap pihak yang bersangkutan.
\end{abstract}

Kata Kunci : Tidak berbuat sesuatu, hak dan kewajiban, perjanjian pinjam meminjam.

\section{A. PENDAHULUAN}

Untuk mewujudkan suatu perjanjian yang telah disepakati bersama, para pihak yang terikat dalam perjanjian dapat melaksanakan isi perjanjian sebagaimana mestinya. Dilaksanakannya prestasi dalam perjanjian, maka apa yang diharapkan sebagai maksud dan tujuan diadakannya perjanjian akan tercipta dengan baik tanpa ada pihak yang dirugikan yang dapat menuntut atas kerugian yang dideritanya. Perjanjian kerja memegang peranan penting dan merupakan sarana untuk mewujudkan hubungan kerja yang baik dalam praktek sehari-hari.
Adanya perjanjian kerja, pengusaha harus mampu memberikan pengarahan/penempatan kerja sehubungan dengan adanya kewajiban mengusahakan pekerjaan atau menyediakan pekerjaan, yang tidak lain untuk mengurangi jumlah pengangguran Indonesia, akibat pertumbuhan penduduk yang semakin tinggi dan penyebaran penduduk yang kurang seimbang sehingga menjadi faktor yang amat mempengaruhi tentang masalah ketenagakerjaan di Indonesia. Namun, saat ini masih banyak pekerja yang tidak mengerti akan hak dan kewajibannya sehingga banyak pekerja yang merasa 
dirugikan oleh pengusaha yang memaksakan kehendaknya pada pihak pekerja dengan memaksakan perjanjian kerja tersebut pada pekerjanya.

Umumnya perjanjian kerja dibuat dalam bentuk perjanjian baku, sehingga isi dari perjanjian tersebut telah dirancang terlebih dahulu oleh pihak pemberi kerja. Pekerja hanya cukup membaca kembali dan menandatanganinya sebagai bentuk kesepakatan atas seluruh isi dari perjanjian kerja tersebut. Kesepakatan tersebut kemudian dikenal dengan istilah konsensualisme, sebagai salah satu syarat sahnya suatu perjanjian. Asas konsensualisme mempunyai hubungan yang erat dengan asas kekuatan mengikat (Pacta Sunt Servanda) atau perjanjian yang dibuat para pihak mengikat pihak-pihak yang membuatnya.

Perjanjian itu mengikat dan masingmasing pihak harus bertanggung jawab terhadap apa yang telah diperjanjikan dalam suatu perjanjian. Hal ini sesuai dengan asas di dalam suatu perjanjian yaitu asas kebebasan berkontrak. Namun, dengan adanya kebebasan berkontrak ini tidak serta merta dapat diterapkan secara absolut dalam pembuatan suatu perjanjian, melainkan terdapat pembatasan. Ketentuan-ketentuan umum yang terdapat dalam Pasal 1320 jo. 1337 Kitab UndangUndang Hukum Perdata yang selanjutnya disebut KUHPdt merupakan acuan pembatasannya. Hal inilah yang menjadi dasar bagi setiap perjanjian, begitu pula dalam perjanjian kerja. Ketentuan Pasal 1337 memberikan pembatasan terhadap obyek yang diperjanjikan harus merupakan suatu sebab yang halal, karena suatu sebab adalah terlarang apabila dilarang oleh undang-undang, atau apabila berlawanan dengan kesusilaan atau ketertiban umum.

Bisa dibayangkan jika klausul ini diakui dan dapat dilaksanakan di Indonesia dengan berlindung pada asas kebebasan berkontrak, maka akan semakin banyak muncul pembatasan-pembatasan dimana seorang pekerja tidak diperbolehkan bekerja pada perusahaan pesaing meskipun hanya untuk waktu tertentu yang bervariasi lamanya. Secara tidak langsung akan berakibat berkurangnya kesempatan dan kebebasan kerja bagi para tenaga kerja di Indonesia. Sebenarnya tujuan dari pencantuman non-competition clause (tanpa persaingan perjanjian) dalam perjanjian kerja tersebut sebagai bentuk perlindungan perusahaan dari kompetitornya.

Jika dalam hal pekerja telah menandatangani perjanjian kerja yang memuat non-competition clause, tentunya pekerja berkewajiban untuk memenuhi klausula tersebut. Jadi, apabila pekerja tidak memenuhi kewajibannya dalam pelaksanaan klausula tersebut, dimungkinkan pekerja telah melakukan pelanggaran perjanjian kerja yang 
kemudian akan merugikan perusahaan tempatnya bekerja.

Berdasarkan asas kebebasan berkontrak, maka sering timbul suatu perjanjian yang isinya mengandung syaratsyarat yang bersifat membatasi tanggung jawab, menghapuskan tanggung jawab, membebaskan tanggung jawab, mengurangi tanggung jawab ataupun meringankan tanggung jawab yang disebut dengan istilah "Klausula Eksonerasi (exenoratie clausule"), klausula ini banyak terdapat pada perjanjian baku (standard contract). Hal yang harus dilakukan bukan melarang atau membatasi penggunaan kontrak baku, melainkan melarang atau membatasi penggunaan klausul-klausul tertentu dalam kontrak baku tersebut.

\section{B. PEMBAHASAN}

Perikatan merupakan Peristiwa hukum, hal tersebut menciptakan hubungan hukum antara pihak yang satu dengan pihak lainnya. Dalam hubungan tersebut, setiap pihak memiliki hak dan kewajiban timbal balik. Dalam hubungan jual-beli, pihak pembeli berposisi sebagai debitor, sedangkan pihak penjual sebagai kreditor. Dalam perjanjian hibah, pihak pemberi hibah berposisi sebagai debitor, sedangkan pihak penerima hibah sebagai kreditor.

Jika dirumuskan, perikatan merupakan suatu hubungan hukum dalam lapangan harta kekayaan antara dua orang atau lebih di mana pihak yang satu berhak atas sesuatu dan pihak lain berkewajiban atas sesuatu. Hubungan hukum dalam harta kekayaan ini merupakan suatu akibat hukum, akibat hukum dari suatu perjanjian atau peristiwa hukum lain yang menimbulkan perikatan, dari rumusan ini dapat diketahui bahwa perikatan itu terdapat dalam bidang hukum harta kekayaan (law of property), juga terdapat dalam bidang hukum keluarga (family law), dalam bidang hukum waris (law of succession) serta dalam bidang hukum pribadi (pers onal law).

Di Dalam ilmu pengetahuan Hukum Perdata, pengertian perikatan adalah suatu hubungan dalam lapangan harta kekayaan antara dua orang atau lebih dimana pihak yang satu berhak atas sesuatu dan pihak lain berkewajiban atas sesuatu, perikatan di sini merupakan hubungan hukum yang bersifat harta kekayaan antara dua orang atau lebih, atas dasar mana pihak yang satu berhak (kreditur) dan pihak lain berkewajiban (debitur) atas suatu prestasi.

Hubungan antara perikatan dan perjanjian adalah demikian, bahwa perikatan itu dilahirkan dari suatu perjanjian. Maka hukum perikatan, terdapat sistem yang terbuka, dan yang dimaksud dengan system terbuka adalah setiap orang dapat mengadakan perikatan yang bersumber pada perjanjian, perjanjian apapun dan bagaimanapun, baik itu yang diatur dengan undang- 
undang atau tidak, inilah yang disebut dengan kebebasan berkontrak, dengan syarat kebebasan berkontrak harus halal, dan tidak melanggar hukum, sebagaimana yang telah diatur dalam Undang-undang. Perikatan itu merujuk pada perikatan untuk berbuat sesuatu dan untuk tidak berbuat sesuatu. Yang dimaksud dengan perikatan untuk berbuat sesuatu adalah melakukan perbuatan yang sifatnya positif, halal, tidak melanggar undangundang dan sesuai dengan perjanjian. Sedangkan perikatan untuk tidak berbuat sesuatu yaitu untuk tidak melakukan perbuatan tertentu yang telah disepakati dalam perjanjian.

Subjek perikatan disebut juga pelaku perikatan. Perikatan yang dimaksud meliputi perikatan yang terjadi karena perjanjian dan karena ketentuan UndangUndang. Pelaku perikatan terdiri atas manusia pribadi dan dapat juga badan hukum atau persekutuan. Setiap pelaku perikatan yang mengadakan perikatan harus:

1. Ada kebebasan menyatakan kehendaknya sendiri;

2. Tidak ada paksaan dari pihak manapun;

3. Tidak ada penipuan dari salah satu pihak, dan

4. Tidak ada kekhilafan pihak-pihak yang bersangkutan.

Setiap pihak dalam dalam perikatan harus wenang berbuat menurut hukum dalam mencapai persetujuan kehendak (ijab kabul). Persetujuan kehendak adalah pernyataan saling memberi dan menerima secara riil dalam bentuk tindakan nyata, pihak yang satu menyatakan memberi sesuatau kepada yang dan menerima seseuatu dari pihak lain. Dengan kata lain, persetujuan kehendak (ijab kabul) adalah pernyataan saling memberi dan menerima secara riil yang mengikat kedua pihak. Setiap hak dalam perikatan harus memenuhi syarat-syarat wewenang berbuat menurut hukum yang ditentukan oleh undang-undang Pasal 330 Kitab Undang-Undang Hukum Perdata.

Persetujuan pihak merupakan perjanjian yang dilakukan oleh dua pihak untuk saling memenuhi kewajiban dan saling memperoleh hak dalam setiap perikatan. Persetujuan kehendak juga menetukan saat kedua pihak mengakhiri perikatan karena tujuan pihak sudah tercapai. Oleh sebab itu, dapat dinyatakan bahwa perikatan menurut sistem hukum prdata, baru dalam taraf menimbulkan kewajiban dan hak pihak-pihak, sedangkan persetujuan kehendak adalah pelaksanaan atau realisasi kewajiban dan pihak-pihak sehingga kedua belah pihak memperoleh hak masing-masing.

Bagaimana jika halnya salah satu pihak tidak memenuhi kewajibannya sehingga pihak lainnya tidak memperoleh hak dalam perikatan dalam hal ini dapat dikatakan bahwa pihak yang tidak 
memenuhi kewajibannya itu telah melakukan wanprestasi yang merugikan pihak lain. Dengan kata lain, perjanjian tersebut dilanggar oleh salah satu pihak.

Untuk mengetahui sejak kapan debitor dalam keadaan wanprestasi, perlu diperhatikan apakah dalam perikatan itu ditentukan jangka waktu pelaksanaan pemenuhan prestasi atau tidak. Dalam hal telah ditentukan tenggang waktunya, menurut ketentuan Pasal 1238 KUHPdt debitor dianggap lalai dengan lewatnya tenggang waktu yang telah ditetapkan dalam perikatan.

Peringatan tertulis dapat dilakukan secara resmi dan dapat juga secara tidak resmi. Peringatan tertulis secara resmi dilakukan melalui pengadilan negeri yang berwenang, yang disebut sommatie. Kemudian, pengadilan negeri dengan perantaraan juru sita menyampaikan surat peringatan tersebut kepada debitor yang disertai berita acara penyampaiannya. Peringatan tertulis tidak resmi, misalnya, melalui surat tercatat, telegram, faksimile, atau disampaikan senidri oleh kreditor kepada debitor dengan tanda terima. Surat peringatan ini disebut ingebreke stelling.

Akibat hukum bagi debitor yang telah melakukan wanprestasi adalah hukuman atau sanksi hukum berikut ini:

a. Debitor diwajibkan membayar ganti kerugian yang diderita oleh kreditor terdapat dalam Pasal 1243 KUHPdt. b. Apabila perikatan itutimbal balik, kreditor dapat menuntut pemutusan atau pembatalan perikatan melalui pengadilan menurut Pasal 1266 KUHPdt.

c. Perikatan untuk memberikan sesuatu, risiko beralih kepada debitor sejak terjadi wanprestasi merujuk pada Pasal 1237 ayat (2) KUHPdt.

d. Debitor diwajibkan memenuhi perikatan jika masih dapat dilakukan atau pembatalan disertai pembayaran ganti kerugian yang terdapat pada Pasal 1267 KUHPdt.

e. Debitor wajib membayar biaya perkara jika diperkarakan di muka pengadilan negeri dan debitor dinyatakan bersalah.

Prestasi (performance) dalam hukum kontrak dimaksudkan sebagai suatu pelaksanaan hal-hal yang tertulis dalam suatu kontrak oleh pihak yang telah mengikatkan diri untuk itu, pelaksanaan mana sesuai dengan "term" dan "condition" sebagaimana disebutkan dalam kontrak yang bersangkutan. Model-model dari prestasi terdapat pada Pasal 1234 KUH Perdata.

Ketentuan pasal 1238 KUHPerdata ini hanya mengatur tentang perikatan untuk memberikan sesuatu, sedangkan perikatan untuk berbuat sesuatu tidak ada ketentuan spesifik semacam pasal ini. Namun ketentuan pasal ini dapat juga diikuti oleh perikatan untuk berbuat 
sesuatu. Sebaiknya ketentuan pasal 1238

KUHPerdata ini dapat diperluas juga meliputi perikatan untuk berbuat sesuatu. Jadi dalam penyusunan hukum perikatan nasional nanti ketentuan semacam pasal ini dapat ditiru dan meliputi perikatan untuk memberikan sesuatu dan perikatan untuk berbuat sesuatu.

Hubungan hukum yang menimbulkan hak dan kewajiban dalam perikatan tersebut adalah antara dua pihak. Pihak yang berhak atas prestasi (pihak yang aktif) adalah kreditur atau orang yang berpiutang. Sedangkan pihak yang berkewajiban memenuhi prestasi (pihak yang pasif) adalah debitur atau orang yang berutang. Kreditur dan debitur inilah yang disebut dengan subyek hukum.

Obyek perikatan yang merupakan hak debitur dan kewajban debitur biasanya dinamakan prestasi. Menurut pasal 1234 BW prestasi ini dapat berupa memberisesuatu, berbuat sesuatu dan tidak berbuat sesuatu. Apa yang dimaksud "sesuatu" disini bergantung kepada maksud atau tujuan daripada para pihak yangmengadakan hubungan hukum, apa yang akan diberikan, yang harus diperbuat dan tidak boleh diperbuat.

Sistem hukum perdata mengenal asas kebebasan berkontrak, sebagaimana dianut di dalam KUHPerdata dengan kata lain asas ini disebut dengan freedom of contract atau laissez faire, yang di dalam
Pasal 1338 KUHPerdata dinyatakan, semua perjanjian yang dibuat secara sah, berlaku halnya sebagai undang-undang bagi mereka yang membuatnya.

Perjanjian mempunyai kekuatan mengikat, sama kekuatannya dengan undang-undang, bagi mereka yang melakukan perjanjian. Dalam KUHPerdata Buku ke-III, tentang Perikatan, termuat ketentuan-ketentuan tentang subjek-subjek hukum dari perikatan, syarat-syarat perikatan, tentang resiko-resiko jenis perikatan tertentu, syarat-syarat pembatalannya, dan berbagai bentuk perikatan yang dapat diadakan (Pasal 1233).

Perjanjian berlaku bagi pihak yang melakukan perjanjian itu, mempunyai konsekuensi bahwa hanya kepada pihak yang ikut melakukan perjanjian itulah berlaku perjanjian itu, dengan demikian, pihak ketiga atau pihak luar tidak dapat menuntut suatu hak berdasarkan perjanjian yang dilakukan pihak-pihak yang melakukan perjanjian tersebut. Berlakunya perjanjian hanya kepada pihak-pihak yang melakukan suatu perjanjian disebut dengan privities of contract.

Persetujuan itu tidak dapat ditarik kembali selain dengan kesepakatan kedua belah pihak, atau karena alasan-alasan yang ditentukan oleh undang-undang. Persetujuan harus dilaksanakan dengan itikad baik yaitu keinginan subyek hukum 
untuk berbuat sesuatu, kemudian mereka mengadakan negosiasi dengan pihak lain, dan sudah barang tentu keinginan itu sesuatu yang baik. Itikad baik yang sudah mendapat kesepakatan terdapat dalam isi perjanjian untuk ditaati oleh kedua belah pihak sebagai suatu peraturan bersama. Isi perjanjian ini disebut prestasi yang berupa penyerahan suatu barang, melakukan suatu perbuatan, dan tidak melakukan suatu perbuatan. Supaya terjadi persetujuan yang sah, perlu dipenuhi 4 syarat:

1. Kesepakatan mereka yang mengikatkan diri.

2. Kecakapan untuk membuat suatu perikatan.

3. Suatu pokok persoalan tertentu.

4. Suatu sebab yang tidak terlarang.

Dua syarat pertama disebut juga dengan syarat subyektif, sedangkan syarat ketiga dan keempat disebut syarat obyektif. Dalam hal tidak terpenuhinya unsur pertama (kesepakatan) dan unsur kedua (kecakapan) maka kontrak tersebut dapat dibatalkan. Sedangkan apabila tidak terpenuhinya unsur ketiga (suatu hal tertentu) dan unsur keempat (suatu sebab yang halal) maka kontrak tersebut adalah batal demi hukum.

Berdasarkan pasal 1320 jo 1338 ayat (1) BW/KHUPPerdata dikenal adanya asas konsesual, yang dimaksud adalah bahwa perjanjian/kontrak lahir pada saat terjadinya konsesnsi/sepakat dari para pihak pembuat kontrak terhadap obyek yang diperjanjikan.

Perikatan yang timbul karena perjanjian, tidak dipenuhi atau dilanggarnya butir-butir perjanjian itu, setelah dipenuhinya syarat tertentu, dapat mengakibatkan terjadinya cedera janji (wanprestatie). Perbuatan cedera janji ini memberikan hak pada pihak yang dicederai janji untuk menggugat ganti rugi berupa biaya, kerugian, dan bunga (Pasal 1236 dalam hal perjanjian memberikan sesuatu, Pasal 1239, dan Pasal 1242 dalam hal perjanjian berbuat atau tidak berbuat sesuatu, Pasal 1234, 1244, 1246) dan seterusnya.

Kesepakatan yang dibuat secara semu atau tidak murni harus dianggap batal secara yuridis. Pasal 1321 KUHPerdata menentukan persetujuan, yang bersifat semu atau tidak murni ialah persetujuan yang dibuat karena adanya kesilapan (dwaling, mistake), adanya paksaan (dwang, duress), dan adanya penipuan (bedrog, misrepresentation).

Jadi secara tidak langsung di dalam Pasal 1242 yang berbunyi "Jika perikatan itu bertujuan untuk tidak berbuat sesuatu, maka pihak mana pun yang berbuat bertentangan dengan perikatan itu, karena pelanggaran itu saja, diwajibkan untuk mengganti biaya, kerugian dan bunga". Pasal ini dengan jelas jika seseoarang atau debitur atau kreditur malanggar isi perjanjian yang telah disepakati oleh 
kedua belah pihak maka harus menanggung kerugian atau mengganti kerugian tersebut beserta bunganya.

Sesuai Pasal 1242 Kitab UndangUndang Hukum Perdata jika dari awal memungkinkan seseorang akan melakukan tindakan tidak memenuhi prestasi maka bisa dilakukan pembatalan suatu perjanjian atau perikatan, Pembatalan perjanjian, bertujuan membawa kedua belah pihak kembali pada keadaan sebelum perjanjian diadakan. Dikatakan bahwa pembatalan itu berlaku surut sampai pada detik dilahirkannya perjanjian. Kalau suatu pihak sudah menerima sesuatu dari pihak yang lain, baik uang maupun barang, maka itu harus dikembalikan. Pokoknya, perjanjian itu ditiadakan.

\section{PENUTUP}

Dalam hal bentuk prestasi debitur dalam perjanjian yang berupa tidak berbuat sesuatu, akan mudah ditentukan sejak kapan debitur melakukan wanprestasi yaitu sejak pada saat debitur berbuat sesuatu yang tidak diperbolehkan dalam perjanjian. Tidak berbuat sesuatu di dalam perjanjian merupakan bentuk pemenuhan perikatan karena hal tersebut merupakan bentuk pemenuhan prestasi setiap pihak yang memiliki hak dan kewajiban timbal balik sehingga perikatan merupakan hubungan dalam lapangan harta kekayaan antara dua orang atau lebih dimana pihak yang satu berhak atas sesuatu dan pihak lain berkewajiban atas sesuatu, perikatan di sini merupakan hubungan hukum yang bersifat harta kekayaan antara dua orang atau lebih, atas dasar mana pihak yang satu berhak (kreditur) dan pihak lain berkewajiban (debitur) atas suatu prestasi, jika salah seorang tidak memenuhi perikatannya maka hal 1 tersebut bisa disebut wanprestasi.

Bentuk Ganti Rugi Jika Seseorang Berbuat Sesuatu Dalam Perjanjian yaitu membayar biaya, sebagai segala pengeluaran atau perongkosan yang nyata-nyata sudah dikeluarkan oleh satu pihak. Jika seorang sutradara mengadakan suatu perjanjian dengan pemain sandiwara untuk mengadakan suatu pertunjukan dan pemain tersebut tidak datang sehingga pertunjukan terpaksa dibatalkan, maka yang termasuk biaya adalah ongkos cetak iklan, sewa gedung, sewa kursi dan lain-lain, selain itu kerugian dimaksudkan adalah kerugian karena kerusakan barangbarang kepunyaan kreditur yang diakibatkan oleh kelalaian si debitur.

\section{DAFTAR PUSTAKA}

Ahmad ichsan. Hukum Perdata IB. Pembimbing Masa, Bandung, 2010.

Abdul kadir Muhammad. Hukum Perjanjian. Alumni Bandung,2000. 
Ashofa Burhan, Metode PenelitianHukum, Rineka Cipta, Jakarta, 2000.

Abdulkadir, Muhammad. Hukum Perjanjian. Bandung : Alumni. 1980.

Budiono, Herlien. Ajaran Umum Hukum Perjanjian dan Penerapannya di Bidang Kenotariatan", Bandung : Citra Aditya. 2010.

Imam Soepomo. Pengantar Hukum Perburuhan. Djambatan. 2001.

Lalu Husni. Pengantar Hukum Ketenagakerjaan Indonesia. GrafindoPersada Mataram 2003.

Muhammad, Abdulkadir . Hukum Perdata Indonesia" ,Bandung: Citra Aditya Bakti. 2011.

Mertokusumo, Sudikno, Pengantar Hukum Perdata Tertulis $(B W)$, Yogyakarta : Sinar Grafika. 2002.

M. Yahya Harahap. Segi-segi Hukum Perjanjian. Alumni, Bandung. 2009.

Mariam darus Badrulzaman, Perjanjian Kredit Bank. Alumni Bandung, 2005.

Peter Mahmud Marzuki. Penelitian Hukum. Kencana Prenada Media Grop, Jakarta. 2010.

R. Subekti, Jaminan-jaminan Untuk Pemberian Kredit Menurut Hukum Indonesia, Seksi Hukum adat Fakultas Hukum Universitas Gajah Mada. 2003.
Undang-Undang Nomor 12 Tahun 1995 tentang Pemasyarakatan

keputusan menteri kehakiman Republik Indonesia Nomor : M. 02PK.04.10 tahun 1990 tentang pola pembinaan narapidana atau tahanan 